\title{
QUALITY OF GROUND WATER OF JAIPUR CITY, RAJASTHAN (INDIA) AND ITS SUITABILITY FOR DOMESTIC AND IRRIGATION PURPOSE
}

\author{
R. K. TATAWAT ${ }^{1}-$ C.P.SINGH CHANDEL ${ }^{2 *}$ \\ Department Of Chemistry, University of Rajasthan \\ Jaipur - 302004 (Rajasthan) India. \\ *Corresponding author \\ e-mail: chandelcps@ rediffmail.com
}

(Received $16^{\text {th }}$ August 2006; accepted 13rd November 2007)

\begin{abstract}
The groundwater quality of Jaipur city experienced degradation due to rapid urbanization and industrialization. The hydrochemical investigation in the present study is restricted to the major ions concentrations, distributions, their relative abundance, and the pattern of the variability in groundwater chemistry. On the basis of the groundwater chemistry an evaluation of groundwater for domestic and irrigation uses is established. Eleven ground water samples were collected from Jaipur City, Rajasthan (India) from different hand pumps to study the chemical parameter, such as $\mathrm{pH}$, EC, Total Hardness, Calcium, Magnesium, Sodium, Potassium, Carbonate, Bicarbonate, Sulphate, and Chloride, with the help of standard method of APHA during pre-monsoon (April 2006 to June 2006).
\end{abstract}

Keywords: Jaipur City, ground water, pre-monsoon, physico-chemical parameter, hydrochemistry

\section{Introduction}

Water is nature's most wonderful, abundant and useful compound and it is the basis of all lives-ecological resources for the flora and fauna of our earth and a fundamental necessity for all lives. Without a properly functioning water supply, it is difficult to imagine productive human activity, be it agriculture or forestry, livestock, farming or fisheries, trade or industry.

The quality of water is of upper most importance compared to quantity in any water supply planning and especially for drinking purposes purity is equally important. The chemical, physical and bacterial characteristics of ground water determine its usefulness for municipal, commercial, industrial, agricultural, and domestic water supplies[17].

Jaipur City (Longitude: $95^{\circ} 24^{\prime} \mathrm{E}$; latitude: $27^{\circ} 18^{\prime} \mathrm{N}$ ), the capital city of Rajasthan (INDIA) is one of the fastest growing cities in the country, is undergoing rapid urbanization and industrialization. Urbanization has led to immense pressure on ground water resources and has resulted in quality deterioration of ground water as well.

\section{Review of literature}

Various workers in our country have carried out extensive studies on Water Quality. Abbasi [1] et al and Jagdap Jyashri [5] et al have studied water quality of different rivers. Shriniwas [14] et al and Jha [7] et al studied water quality in Hydrabad and Bihar, respectively. Patnaik [8] et al reported water pollution in industrial area. Fluoride level in drinking water from various sources in and around Jaipur and in many villages and trace metals have been carried out in our laboratory [6-11] earlier. Studies of industrial wastewater and ground water and pollution problem in ground water have 
also been studied in our laboratory [12-13] recently. The objective of the scientific investigations is to determine the hydrochemistry of the ground water and to classify the water in order to evaluate the water suitability for drinking, domestic and irrigation uses and its suitability for municipal, agricultural and industrial use.

\section{Materials and methods}

Ground water samples from different hand pumps of eleven sampling points were analyzed during pre-monsoon (April, 2006 to June, 2006). Samples were collected in good quality polyethylene bottles of one-litre capacity. Sampling has been carried out without adding any preservatives in well-rinsed bottles. Only high pure (AnalR grade) chemicals and double distilled water was used for preparing solution for analysis.

Various physical parameters like $\mathrm{pH}, \mathrm{EC}$, and TDS were determined at the site with the help of digital portable water analyzer kit (CENTURY-CK-710). Calcium $\left(\mathrm{Ca}^{2+}\right)$, Magnesium $\left(\mathrm{Mg}^{2+}\right)$, Chloride $\left(\mathrm{Cl}^{-}\right)$, Carbonate $\left(\mathrm{CO}_{3}{ }^{2-}\right)$ and Bicarbonate $\left(\mathrm{HCO}_{3}{ }^{-}\right)$and Sulphate $\left(\mathrm{SO}_{4}{ }^{2-}\right)$ by volumetric titration methods; while Sodium $\left(\mathrm{Na}^{+}\right)$and Potassium $\left(\mathrm{K}^{+}\right)$by Flamephotometry (ELICO-CL-220) (APHA [2] et al, 1985). The sodium adsorption ratio (SAR) values of each water sample were calculated by using Richard [10] equation and the total hardness $(\mathrm{TH})$ in $\mathrm{ppm}$ and the sodium percentage $(\mathrm{Na} \%)$ values were determined using the equations Todd [15].

The respective values for all these parameters are reported in Table 1 and Table 2; all results are compared with standard limit recommended by the Bureau of Indian Standards (BIS), Indian Council of Medical Research (ICMR), and WHO.

\section{Results and discussion}

The concentration of cations and anions are incorporated in Table 1. Classification of waters depends on the principle of the IAH (International Association of Hydrogeologist)[4], 1979. Total equivalents of cations and anions were taken as $100 \%$ and ions, as more than $20 \%$ (meq/L), were evaluated in the classification. Other Physico-chemical parameters are shown in Table 2. Physico-chemical properties of ground water of Jaipur City Compared to Standards are shown in Table 3.

\section{Groundwater quality for drinking water purposes}

$p H$

It was observed from the $\mathrm{pH}$ value that water samples were varying from 7.40 to 8.03 and these values are within the limits prescribed by ISI, ICMR (Table 3) the ground water sample collected from $\mathrm{J}-13$ show $\mathrm{pH}$ value of 9.78 that is higher than the permissible limit and indicates that water is slightly alkaline.

\section{Electrical Conductivity (EC)}

$\mathrm{EC}$ of the groundwater is varying from 345 to 2550 microsiemens $/ \mathrm{cm}$ at $25^{\circ} \mathrm{C}$.the maximum limit of EC in drinking water is prescribed as 1400 microsiemens/cm (WHO: 2003) Samples (J-10, J-14, J-17 and J-21) exceed the permissible limit. 


\section{Total Dissolving Solids (TDS)}

The total dissolved solids in water are represented by the weight of residue left when a water sample has been evaporated to dryness. TDS values varied from 239.6 to 1435 $\mathrm{mg} / \mathrm{l}$ except J-6, J-12, J-13, J-24; all remaining samples exceed the permissible limit prescribed by WHO $(500 \mathrm{mg} / \mathrm{l})$ and ICMR $(600 \mathrm{mg} / \mathrm{l})$.

Table 1. Ionic variation in ground water of Jaipur City

\begin{tabular}{|c|c|c|c|c|c|c|c|c|c|c|}
\hline Code & Unit & $\mathrm{Ca}^{2+}$ & $\mathrm{Mg}^{2+}$ & $\mathrm{Na}^{+}$ & $\mathbf{K}^{+}$ & $\mathrm{Co}_{3}{ }^{2-}$ & $\mathrm{HCO}_{3}^{-}$ & $\mathrm{Cl}^{-}$ & $\mathrm{So}_{4}{ }^{2-}$ & Water type \\
\hline \multirow{3}{*}{$\mathrm{J}-1$} & ppm & 14.03 & 34.05 & 200 & 4.10 & 30 & 196 & 204.94 & 10 & $\mathrm{Na}-\mathrm{Mg}-\mathrm{Cl}-\mathrm{HCO}_{3}$ \\
\hline & epm & 0.70 & 2.80 & 8.70 & 0.10 & 1.00 & 3.21 & 5.78 & 0.21 & \\
\hline & $\%$ & 5.69 & 22.76 & 70.70 & 0.85 & 9.80 & 31.49 & 56.66 & 2.04 & \\
\hline \multirow{3}{*}{$\mathrm{J}-6$} & ppm & 20.04 & 6.08 & 134 & 0.90 & 42 & 237.90 & 54.48 & 47.85 & $\mathrm{Na}-\mathrm{HCO}_{3}$ \\
\hline & epm & 1.00 & 0.50 & 5.83 & 0.02 & 1.40 & 3.90 & 1.54 & 1.00 & \\
\hline & $\%$ & 13.60 & 6.80 & 79.28 & 0.31 & 17.87 & 49.79 & 19.62 & 12.72 & \\
\hline \multirow{3}{*}{$\mathrm{J}-10$} & $\mathrm{ppm}$ & 254.50 & 24.32 & 164 & 5.50 & ND & 396.50 & 624.81 & 112.50 & $\mathrm{Ca}-\mathrm{Na}-\mathrm{Cl}-\mathrm{HCO}_{3}$ \\
\hline & epm & 12.70 & 2.00 & 7.13 & 0.14 & & 6.50 & 17.63 & 2.34 & \\
\hline & $\%$ & 57.79 & 9.10 & 32.46 & 0.64 & & 24.56 & 66.59 & 8.85 & \\
\hline \multirow{3}{*}{$\mathrm{J}-12$} & ppm & 30.06 & 36.48 & 37 & 0.60 & $\mathrm{ND}$ & 259.25 & 37.49 & 11.61 & $\mathrm{Mg}-\mathrm{Na}-\mathrm{Ca}-\mathrm{HCO}_{3}$ \\
\hline & epm & 1.50 & 3.00 & 1.61 & 0.02 & & 4.25 & 1.06 & 0.24 & \\
\hline & $\%$ & 24.49 & 48.98 & 26.28 & 0.25 & & 76.59 & 19.06 & 4.36 & \\
\hline \multirow{3}{*}{$\mathrm{J}-13$} & ppm & 10.02 & 3.65 & 65 & 1.50 & 42 & 6.10 & 37.49 & 74.58 & $\mathrm{Na}-\mathrm{SO}_{4}-\mathrm{CO}_{3}-\mathrm{Cl}$ \\
\hline & epm & 0.50 & 0.30 & 2.83 & 0.04 & 1.40 & 0.10 & 1.06 & 1.55 & \\
\hline & $\%$ & 13.64 & 8.19 & 77.13 & 1.05 & 34.06 & 2.43 & 25.73 & 37.78 & \\
\hline \multirow{3}{*}{$\mathrm{J}-14$} & ppm & 64.13 & 107.01 & 93 & 3.20 & 6 & 207.40 & 227.43 & 104.40 & $\mathrm{Mg}-\mathrm{Na}-\mathrm{Ca}-\mathrm{Cl}-\mathrm{HCO}_{3}$ \\
\hline & epm & 3.20 & 8.80 & 4.05 & 0.08 & 0.20 & 3.40 & 6.42 & 2.17 & \\
\hline & $\%$ & 19.84 & 54.57 & 25.08 & 0.51 & 1.64 & 27.89 & 52.63 & 17.83 & \\
\hline \multirow{3}{*}{$\mathrm{J}-17$} & ppm & 130.26 & 126.46 & 54 & 2.80 & ND & 183 & 399.87 & 96.32 & $\mathrm{Mg}-\mathrm{Ca}-\mathrm{Cl}$ \\
\hline & epm & 6.50 & 10.40 & 2.35 & 0.07 & & 3.00 & 11.28 & 2.01 & \\
\hline & $\%$ & 33.64 & 53.83 & 12.16 & 0.37 & & 18.42 & 69.26 & 12.31 & \\
\hline \multirow{3}{*}{$\mathrm{J}-18$} & ppm & 20.04 & 24.32 & 190 & 2.40 & 33 & 423.95 & 82.47 & 37.11 & $\mathrm{Na}-\mathrm{HCO}_{3}-\mathrm{Cl}$ \\
\hline & epm & 1.00 & 2.00 & 8.26 & 0.06 & 1.10 & 6.95 & 2.33 & 0.77 & \\
\hline & $\%$ & 8.83 & 17.66 & 72.97 & 0.54 & 9.87 & 62.34 & 20.87 & 6.93 & \\
\hline \multirow{3}{*}{$\mathrm{J}-19$} & $\mathrm{ppm}$ & 30.06 & 79.04 & 271 & 2.30 & 15 & 503.25 & 179.94 & 60.46 & $\mathrm{Na}-\mathrm{Mg}-\mathrm{HCO}_{3}-\mathrm{Cl}$ \\
\hline & epm & 1.50 & 6.50 & 11.79 & 0.06 & 0.50 & 8.25 & 5.08 & 1.26 & \\
\hline & $\%$ & 7.56 & 32.75 & 59.39 & 0.30 & 3.31 & 54.69 & 33.65 & 8.34 & \\
\hline \multirow{3}{*}{$\mathrm{J}-21$} & ppm & 90.18 & 111.87 & 132 & 7.60 & 24 & 420.90 & 402 & 112.35 & $\mathrm{Mg}-\mathrm{Na}-\mathrm{Ca}-\mathrm{Cl}-\mathrm{HCO}_{3}$ \\
\hline & epm & 4.50 & 9.20 & 5.74 & 0.19 & 0.80 & 6.90 & 11.34 & 2.34 & \\
\hline & $\%$ & 22.92 & 46.85 & 29.24 & 0.99 & 3.74 & 32.27 & 53.04 & 10.94 & \\
\hline \multirow{3}{*}{$\mathrm{J}-24$} & ppm & 26.05 & 20.67 & 53 & 2.50 & 36 & 195.20 & 32.49 & 4.90 & $\mathrm{Na}-\mathrm{Mg}-\mathrm{Ca}-\mathrm{HCO}_{3}$ \\
\hline & epm & 1.30 & 1.70 & 2.31 & 0.06 & 1.20 & 3.20 & 0.92 & 0.10 & \\
\hline & $\%$ & 24.21 & 31.66 & 42.94 & 1.19 & 22.15 & 59.06 & 16.91 & 1.88 & \\
\hline
\end{tabular}

Calcium $\left(\mathrm{Ca}^{2+}\right)$

Calcium concentrations are varying from 10.02 to $254.50 \mathrm{mg} / \mathrm{l}$ and except $\mathrm{J}-10$; all samples are within permissible limit prescribed by ICMR. 
Table 2. Physico-chemical parameters of groundwater of Jaipur city

\begin{tabular}{c|c|c|c|c|c|c}
\hline CODE & pH & EC & TDS & TH & SAR & Na\% \\
\hline J-4 & 7.72 & 1149 & 611.50 & 175.15 & 6.58 & 71.55 \\
J-6 & 7.9 & 791 & 445.00 & 75.06 & 6.73 & 79.60 \\
J-10 & 7.4 & 2540 & 1435.14 & 735.56 & 2.63 & 33.10 \\
J-12 & 7.73 & 587 & 296.69 & 225.18 & 1.07 & 26.53 \\
J-13 & 9.78 & 345 & 239.46 & 40.04 & 4.47 & 78.17 \\
J-14 & 7.84 & 1596 & 785.64 & 600.48 & 1.65 & 25.59 \\
J-17 & 7.56 & 2550 & 982.57 & 845.64 & 0.81 & 12.53 \\
J-18 & 8.03 & 1130 & 654.79 & 150.12 & 6.75 & 73.51 \\
J-19 & 7.76 & 1704 & 961.63 & 400.31 & 5.89 & 59.69 \\
J-21 & 7.56 & 2430 & 1112.60 & 685.52 & 2.19 & 30.23 \\
J-24 & 7.93 & 540 & 275.85 & 150.10 & 1.88 & 43.80 \\
\hline
\end{tabular}

\section{Magnesium $\left(\mathrm{Mg}^{2+}\right)$}

Magnesium concentration varies from 3.65 to $126.46 \mathrm{mg} / \mathrm{l}$ and these values are within permissible limits prescribed by ISI, ICMR, WHO.

\section{Total Hardness (TH)}

In most water nearly all the hardness is due to calcium and magnesium. All the metallic cations besides the alkali metals also cause hardness. Total Hardness is varying from 40.04 to $845.64 \mathrm{mg} / \mathrm{l}$ and these values are within the permissible limit prescribe by ISI, ICMR and WHO except J-10, J-14, J-17, J-21.

\section{Sodium $\left(\mathrm{Na}^{+}\right)$and Potassium $\left(\mathrm{K}^{+}\right)$}

Large amounts give a salty taste when combined with chloride. Moderate quantities have little effect on the usefulness of water for most purposes. Sodium and potassium concentrations are varying from 20.67 to $200 \mathrm{mg} / \mathrm{l}$ and 0.6 to $7.6 \mathrm{mg} / \mathrm{l}$ respectively.

\section{Chloride $\left(\mathrm{Cl}^{-}\right)$}

Chloride concentration are varying from 32.49 to $624.81 \mathrm{mg} / \mathrm{l}$ which are lower than the prescribed by ICMR and WHO standards except for J-17, J-21, J-10. In sample (J10) chloride concentration is very high $(624.81 \mathrm{mg} / \mathrm{l})$. Unusual Concentration may indicate pollution by organic waste.

Chloride salts in excess of $100 \mathrm{mg} / 1$ give salty taste to water. When combined with calcium and magnesium, may increase the corrosive activity of water. It is recommended that chloride content should not exceed $250 \mathrm{mg} / 1$.

\section{Carbonate (CO32-) and Bicarbonate (HCO3-)}

Carbonate and Bicarbonate concentration are varying from 6 to $42 \mathrm{mg} / \mathrm{l}$ and 6.10 to $503.25 \mathrm{mg} / \mathrm{l}$ respectively. 
Sulphate $\left(\mathrm{SO}_{4}{ }^{2-}\right)$

Sulphate concentration is varying from 8.55 to $112.5 \mathrm{mg} / \mathrm{l}$ and these values are within permissible limits prescribed by ISI, ICMR and WHO.

Table 3. Standards for drinking water quality

\begin{tabular}{c|c|c|c|c}
\hline S. No. & Parameters & BIS: $\mathbf{1 9 9 9}$ & ICMR: 1975 & WHO: 2003 \\
\hline 1. & $\mathrm{pH}$ & $6.5-8.5$ & $7.0-8.5$ & $6.5-9.5$ \\
2. & $\mathrm{EC}(\mu$ seimens/cm) & - & - & 1400 \\
3. & $\mathrm{TDS}$ & 2000 & 500 & 600 \\
4. & $\mathrm{Na}^{+}$ & - & - & - \\
5. & $\mathrm{~K}^{+}$ & - & - & - \\
6. & $\mathrm{Ca}^{2+}$ & 200 & 200 & 100 \\
7. & $\mathrm{Mg}^{2+}$ & 100 & 200 & 150 \\
8. & $\mathrm{Cl}^{-}$ & 1000 & 200 & 250 \\
9 & $\mathrm{CO}_{3}^{2-}$ & - & - & - \\
10 & $\mathrm{HCO}_{3}^{-}$ & - & - & - \\
11 & $\mathrm{SO}_{4}^{2-}$ & 400 & 200 & 250 \\
12 & $\mathrm{NO}_{3}^{-}$ & 100 & 50 & 50 \\
13 & $\mathrm{TH}^{-}$ & 600 & 600 & 500 \\
\hline
\end{tabular}

Note: All values except $\mathrm{pH}$ and $\mathrm{EC}$ are expressed in $\mathrm{mg} / \mathrm{l}$.

TDS $=$ Total Dissolved Solids

$\mathrm{EC}=$ Electrical Conductance

$\mathrm{TH}=$ Total Hardness

\section{Chemical classification of ground water}

\section{Hill-Piper Diagram}

One method of comparing the results of chemical analyses of ground water is with a trilinear diagram [9] (Figure 1). This diagram consists of two lower triangles that show the percentage distribution, on the milliequivalent basis, of the major cations $\left(\mathrm{Mg}^{++}\right.$ $\mathrm{Ca}^{++}$, and $\mathrm{Na}^{+}$plus $\mathrm{K}^{+}$) and the major anions $\left(\mathrm{Cl}^{-}, \mathrm{SO} 4{ }^{2-}\right.$ and $\mathrm{CO}_{3}{ }^{2-}$ plus $\left.\mathrm{HCO}_{3}{ }^{-}\right)$and a diamond-shaped part above that summarizes the dominant cations and anions to indicate the final water type. This classification system shows the anion and cation facies in terms of major-ion percentages. The water types are designated according to the area in which they occur on the diagram segments.

The cation distribution indicates that the samples range in composition from sodium/potassium to predominantly mixed cation. There is a small percentage of the ground water that has a calcium cation classification. In the anion triangle, there is a tendency toward chloride/bicarbonate type water to mixed anion-type water. 


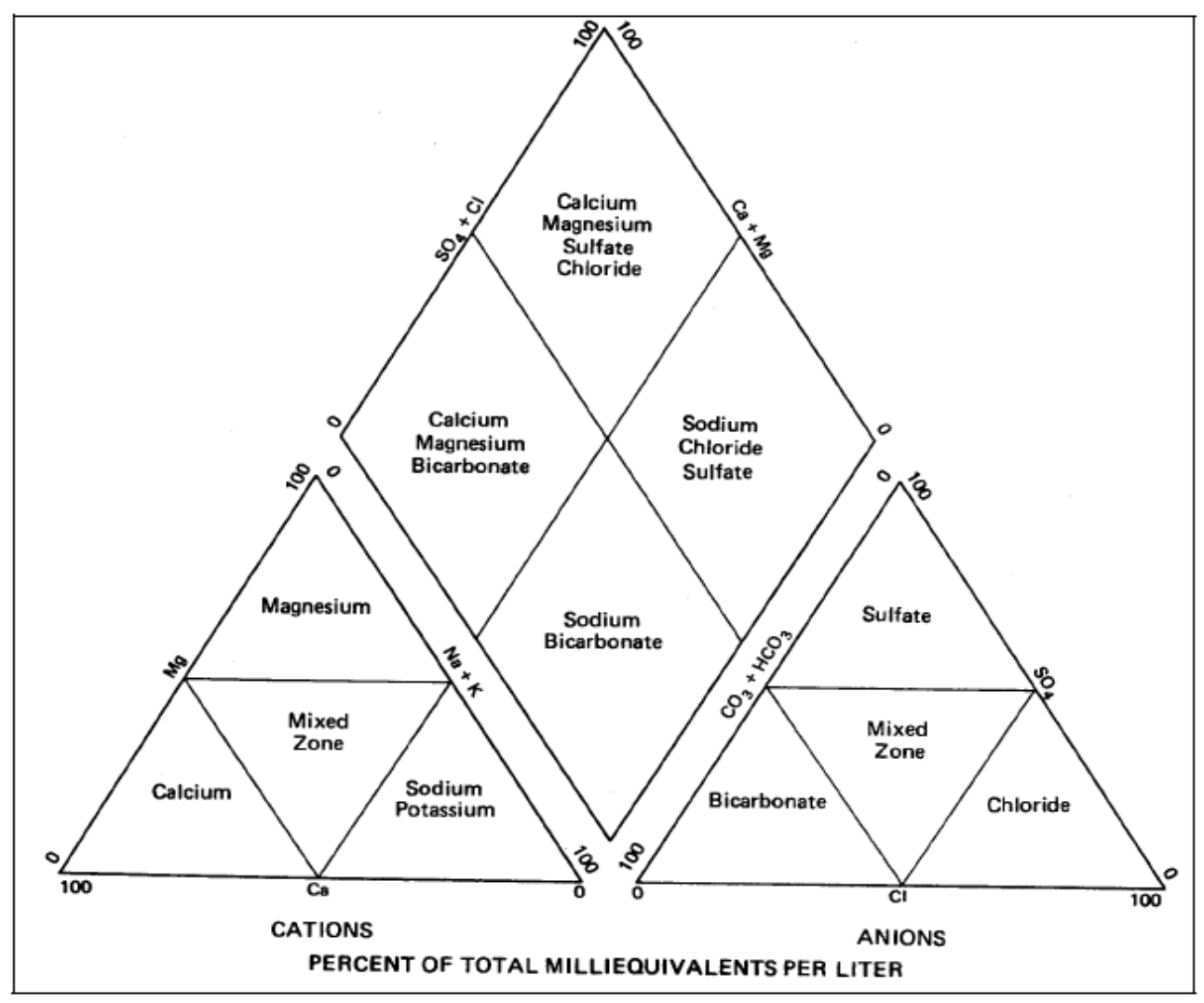

Figure 1. Trilinear diagram showing water type categories

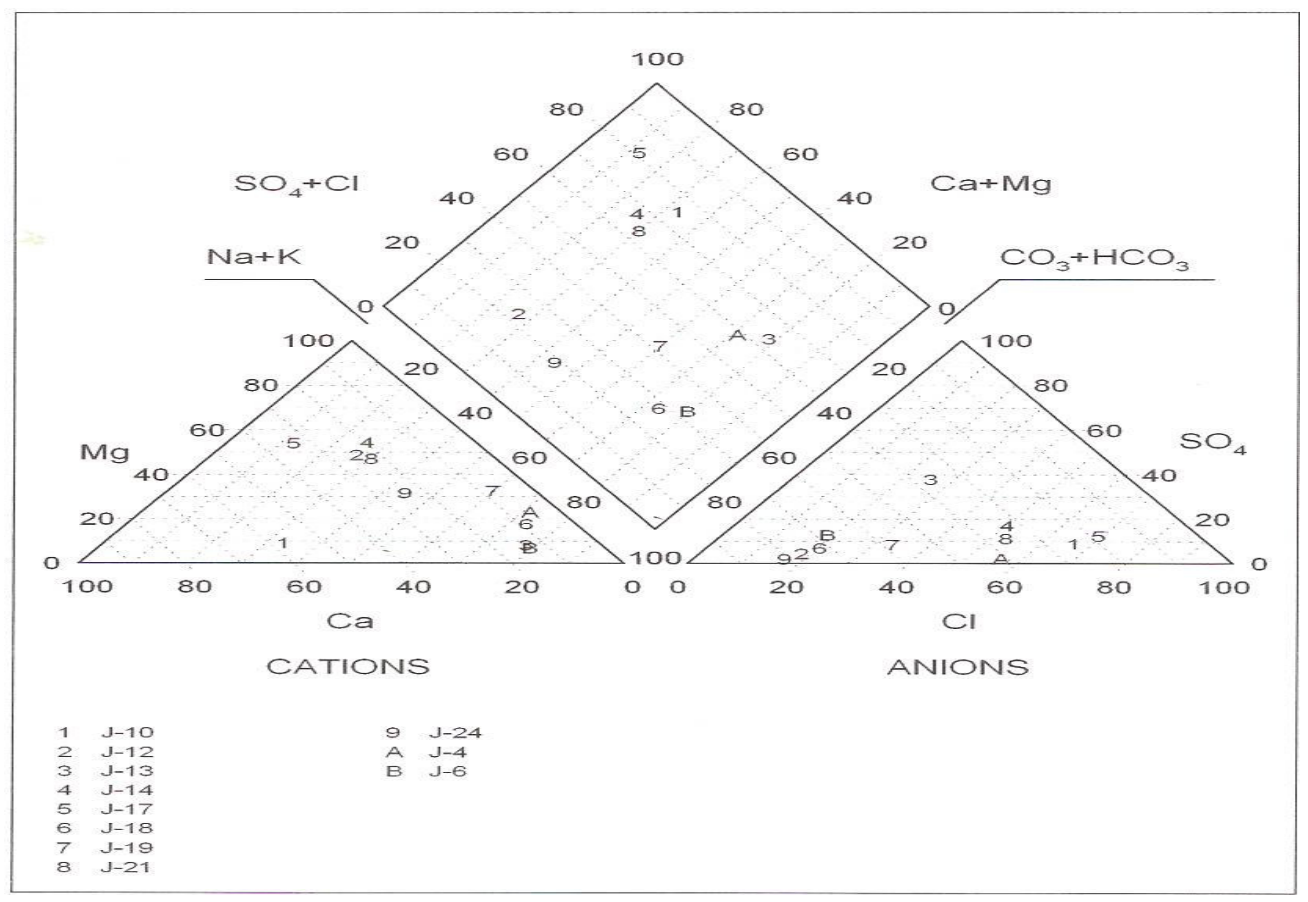

Figure 2. Piper diagram of ground water quality of Jaipur city 


\section{Groundwater quality for irrigation purposes}

The concentration and composition of dissolved constituents in a water determine its quality for irrigation use, several chemical constituents affect water suitability for irrigation from which the total concentration of the soluble salts and the relative proportion of sodium to calcium and magnesium. Moreover suitability of water for irrigation is depended on the effect of some mineral constituents in the water on both the soil and the plant (Wilcox, 1948 \& 1955). The following are the important characteristic properties of ground water of determine its suitability of irrigation proposes.

$T D S$

Regarding to the TDS content the water is considered satisfactory when it contains lesser than $1000 \mathrm{mg} / \mathrm{l}$, fair if it contains between 1000 to $2000 \mathrm{mg} / \mathrm{l}$, and inferior when it salinity exceeds $2000 \mathrm{mg} / \mathrm{l}$. Accordingly, all sampling stations considered suitable for irrigation uses.

$E C$

The most influential water quality guideline on crop productivity is the salinity hazard as measured by electrical conductivity (EC). The primary effect of high EC water on crop productivity is the inability of the plant to compete with ions in the soil solution for water. The higher the EC, the less water is available to plants Nearly all irrigation waters that have been used successfully for a considerable time have conductivity less than 2250 microsiemens $/ \mathrm{cm}$.

\section{Sodium percentage (Na\%)}

The sodium percentage was calculated by Todd's (1959) method:

$$
\mathrm{Na} \%=(\mathrm{Na}+\mathrm{K}) 100 /(\mathrm{Ca}+\mathrm{Mg}+\mathrm{Na}+\mathrm{K}) \quad(\mathrm{epm})
$$

The sodium percentage in the study area ranges between 1.07 to $6.74 \%$. Na\% values reflected that the water was under the category of 'good' (20-40 Na \%), 'permissible' $(40-60 \mathrm{Na} \%)$ and 'doubtful' (60-80 Na\%) class according to Wilcox (1955).

\section{Sodium Absorption Ratio (SAR)}

SAR is an important parameter for determination of Suitability of irrigation water. The sodium hazard is typically expressed as the sodium adsorption ratio (SAR). This index quantifies the proportion of sodium $\left(\mathrm{Na}^{+}\right)$to calcium $\left(\mathrm{Ca}^{++}\right)$and magnesium $\left(\mathrm{Mg}^{++}\right)$ions in a sample. Sodium hazard of irrigation water can be well understood by knowing SAR. Sodium adsorption ratio varied from 0.80 to 6.73 (Table 2). Todd (1980) classified irrigation water with SAR values less than 10 as 'excellent' and the water is evaluated suitable for any crop Lower the ionic strength of Sodium, greater the sodium hazard; and conversely, if Calcium and magnesium predominant, the hazard is low [16]. The sodium adsorption ratio (SAR) values of each water sample were calculated by using Richard (1954) equation: 


$$
\mathrm{SAR}=\left(\mathrm{Na}^{+} \text {meq/l) } / \sqrt{ }\left[\left(\mathrm{Ca}^{2+} \text { meq/l) }+\left(\mathrm{Mg}^{2+} \text { meq/l) } / 2\right.\right.\right.\right.
$$

There is a significant relationship between SAR values of irrigation water and the extent to which sodium is adsorbed by the soil. If the water used for irrigation is high in Sodium and low in Calcium, the cation-exchange complex may become saturated with Sodium. This can destroy the soil structure owing to dispersion of clay particles .The calculated value of SAR in the study area ranges between 1.07 to 6.74. Data is plotted on the US salinity diagram (Figure No. 3), in which EC is taken as salinity hazard and SAR is taken as alkalinity hazard. The ground water samples (J-4, J-6, J-19) fall in the $\mathrm{C}_{3} \mathrm{~S}_{2}$ quality with high salinity hazard and medium sodium hazard. Samples (J-10, J-17, $\mathrm{J}-21$ ) lie in $\mathrm{C}_{4} \mathrm{~S}_{1}$-very high salinity hazard and low sodium hazard. The ground water samples $\left(\mathrm{J}-5, \mathrm{~J}-14\right.$, ) fall in the $\mathrm{C}_{3} \mathrm{~S}_{1}$ quality with high salinity hazard and low sodium hazard. Samples (J-13, J-24, J-12) lie in $\mathrm{C}_{2} \mathrm{~S}_{1}$-medium salinity hazard and low sodium hazard.

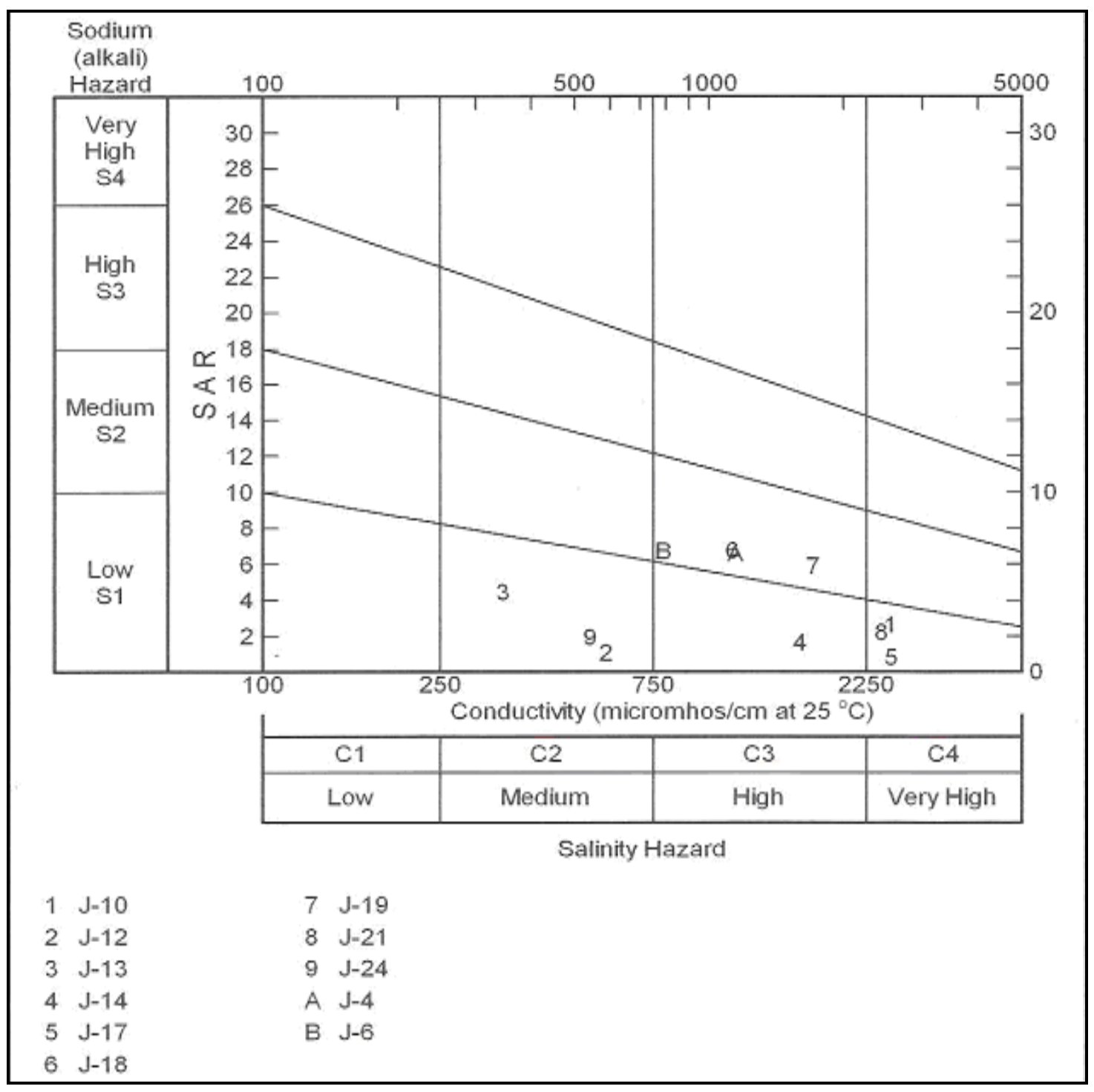

Figure 3. Water classification according to EC and SAR values 


\section{Conclusion}

It is observed that about $36 \%$ of ground water exceeds the permissible limit of EC, TDS and TH prescribed by (WHO: 2003). Almost all the parameters like $\mathrm{pH}, \mathrm{Na}^{+}, \mathrm{K}^{+}$, $\mathrm{Ca}^{2+}, \mathrm{Mg}^{2+}, \mathrm{SO}_{4}{ }^{2-}, \mathrm{CO}_{3}{ }^{-}, \mathrm{HCO}_{3}{ }^{-}$and $\mathrm{Cl}^{-}$are within the permissible limits prescribed by prescribed by ISI, ICMR, WHO. On the other hand all the sampling station considered suitable for irrigation uses according to TDS, EC and SAR value. According to the quality classification of irrigation water proposed by Wilcox (1955), $45 \%$ of the water falls in the doubtful category.

Acknowledgements. One of the author(s) (Rakesh Kumar Tatawat) is thankful to the Head, Chemistry Department for providing the necessary laboratory facilities and also thankful to the CSIR, New Delhi, for the award of a Junior Research Fellowship (JRF).

\section{REFERENCES}

[1] Abbasi S.A., F.I. Khan, K. Sentilvelan and A.Shabudeen (2002): Modelling of Buckinggham Canal Water Quality. - Indian J. Environ. Health. 44(4): 290-297.

[2] APHA (1985): Standard methods for the examination of water and wastewater. American Public Health Association, American Water works Association, Water Pollution Control federation, Washington D .C. $16^{\text {th }}$ edition.

[3] Hem, J. D. (1970): Study and interpretation of the chemical characteristics of natural water (2d ed.) - U.S. Geological Survey Water Supply Paper 1473, 363 p.

[4] IAH (International Association of Hydrogeologist) (1979): Map of mineral and thermal water of Europe. Scale; 1:500,00. - IAH, United Kingdom.

[5] Jagdap Jayashri, Bhushan Kachawe, Leena Deshpande and Prakash Kelkar (2002): Water Quality Assessment of the Purna River for Irrigation Purpose in Buldana District, Maharastra. - Indian J. Environ. Health. 44(3): 247-257.

[6] Jangir, J.P., Alka Sharma, M.P. Singh Sengar and C.M. Gupta (1990): - Indian J. Environmental Protection, 10 (7):515-17.

[7] Jha A.N. and P.K. Verma (2000): Physico-Chemical Property of Drinking Water in Town Area of Godda District Under Santal Pargana, Bihar. - Pollution Research. 19(2): 245-247.

[8] Patnaik, K.N., S.V. Satyanarayan and Rout Swoyam Poor (2002): Water Pollution from major industries in Pradip Area-A Case study. - Indian J. Environ. Health, 44(3): 203211.

[9] Piper, A.M. (1953): A graphic procedure in the geochemical interpretation of water analyses. U.S. Geol. Survey Groundwater Note 12.

[10] Richard, L.A. (1954): Diagnosis and improvement of Saline and Alkali Soils. - Agric. Handbook 60, (U.S. Dept. Agric., Washington, D.C., 160 pp.

[11] Sharma, D.K., J.P. Jangir, C.P.S. Chandel and C.M. Gupta (1988): Studies in quality of water in and around Jaipur: Fluoride levels of Drinking water from various sources in villages around Jaipur. - J. Indian Water Works Association 121-122(1990)

[12] Sharma Surendra Kumar, Vijendra Singh and C.P. Singh Chandel (2004): ground water pollution problem and evaluation of Physico-Chemical properties of Ground Water. Environment and Ecology, 22 (spl-2): 319-324.

[13] Singh Vijendra and C.P. Singh Chandel (2006): Analysis of Wastewater of Jaipur City for Agricultural Use. - Research Journal of Chemistry and Environment. 10(1): 30-33. 
[14] Sriniwas C.H., Ravi Shankar Tiska, C. Venkateshwar, M.S. Satyanarayan Rao and Ravindra R. Reddy (2000): Studies on Ground Water Quality of Hyderabad. - Pollution Research. 19(2): 285-289.

[15] Todd, D.K. (1980): Ground water Hydrology. - John Willey \& sons publishers, New York:

[16] U.S. Salinity Laboratory Staff (1954): Diagnosis and Improvement of Saline and Alkali Soils. - Handbook 60. U.S. Department of Agriculture, Washington, D.C.

[17] Walton, W.C. (1970): Ground water resources evolution, New York, Mc Graw Hill Book Co. 